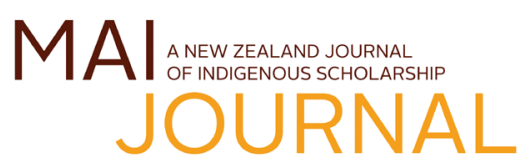

D0I: 10.20507/MAlJournal.2020.9.1.3

\title{
IGNITING THE VĀ
}

\section{Vā-kā methodology in a Māori-Pasifika research fellowship}

\author{
Hinekura Smith* \\ 'Ema Wolfgramm-Foliaki'
}

\begin{abstract}
Drawing on nautical notions of traversing the Pacific Ocean, we seek to encourage Māori and Pasifika researchers to come together in purposeful and transforming ways, not to further homogenise Oceanic identities but, as many sang in active resistance in Aotearoa New Zealand during the 1990s, Kia kotahi ra Te Moana-nui-a-Kiwa ("Unite as one like the Pacific Ocean”). We present Vā-kā as a methodology that emerged from a research fellowship focused on Māori and Pasifika student success at the University of Auckland, New Zealand. Conceptually, we lash together the Pasifika term vā-relational time and space-with the Māori term kā-to ignite, to consider, to be in action. Bound together we forward Vā-kā methodology as a way to ignite Māori and Pasifika researcher relationships, and to share ideas, resources and "crew members" in allegiances that work to positively support our different and similar educational agenda, and seek transforming change for our diverse and complex communities.
\end{abstract}

\section{Keywords}

Indigenous methodology, Māori and Pasifika research, decolonising methodologies, higher education

\section{Introduction}

Māori and Pasifika peoples are people of Te Moana-nui-a-Kiwa, the Pacific Ocean. They are connected through whakapapa, language, ancestral ties and shared (and differing) traditional stories, while simultaneously maintaining and asserting identities that are complex, heterogeneous and directly connect us to the Moana. Our more recent histories of colonisation, capitalism and changing connections to land, language and identity mean that we are regularly and problematically homogenised and defined by the "other". In tertiary education, the terms Māori (who identify themselves in tribal, sub-tribal and whānau groupings) and Pasifika (who identify as family and village collectives within larger island regions) are used as simplistic descriptors to gloss over complex and multilayered identities.

While continuing to interrogate and complexify identities and how they are used in education is important (Anae, 1997; Thaman, 1997; Webber, 2008), this article sets a different course, forwarding a research approach that lashes Māori and Pasifika researchers together in a way that seeks to maintain sovereignty as we support our multiple and diverse educational agenda. Theorising Vā-kā as methodology is a re-voyaging of ancient Moana relationships. It is an attempt

* Te Rarawa, Ngā Puhi. Lecturer, Centre for Learning and Research in Higher Education, University of Auckland, Auckland, New Zealand. Email: hlj.smith@auckland.ac.nz

† Falevai Vava'u, Tongaleleka Ha'apai, 'Atataa, Tonga. Lecturer, Centre for Learning and Research in Higher Education, University of Auckland, Auckland, New Zealand. 
to re-navigate, re-connect and re-ignite in and through the space(s) that bind us as Māori and Pasifika peoples in the context of transformative Moana research.

Moana concepts of voyaging deliberately ebb and flow throughout this article. Te Moana-nuia-Kiwa is the largest body of water on the planet and has for millennia sustained and nurtured our ancestors who learned to live in harmony with its rhythms. From food source to highway, from cleanser of the land through to the holder of stories, the Moana has shaped and formed the identities of its people with each lap of its waves upon islands from the sovereign kingdom of Hawai' $i$ in the north to Rapanui in the east; from the eastern seaboard of Australia in the west and Aotearoa New Zealand in the south. Describing the term Oceania, Hau'ofa (2008) says:

Oceania is vast, Oceania is expanding, Oceania is hospitable and generous, Oceania is humanity rising from the depths of brine and regions of fire deeper still. Oceania is us. We are the sea, we are the ocean, we must wake up to this ancient truth and together use it to overturn all hegemonic views that aim ultimately to confine us again, physically and psychologically, in the tiny spaces that we have resisted accepting as our sole appointed places and from which we have recently liberated ourselves. (p. 39)

Moana languages are rich and embodied, with much of their deeply held knowledge contained within their etymology. Colonising processes disrupted intergenerational language transmission, particularly with te reo Māori in Aotearoa New Zealand, meaning that many of the complex meanings contained within the language have not been transmitted (Fishman, 1996; Harlow, 2005; O’Regan, 2011). Māori scholar Taina Pohatu (2011) describes te reo Māori as a "library of language" deposited by generations and holding potential solutions for today's problems within its immense tomes of knowledge-for those who have the eyes to read it (p. 3). Indigenous scholars are encouraged to innovate, adapt and draw on the knowledge contained within our Indigenous and Moana languages and ways of being. Here we boldly go one step further to draw together a Māori term with a Pasifika term to create a new idea from old knowledge. It is on the "high tide" of Moana scholarship, rich with language, knowledge, theory and history that we set our course

The choice of terminology in a Vā-kā theorisation is important to our argument as "old" language is theorised and lashed together in "new" ways. Choosing terms such as Moana over Oceanic, and Pasifika over Pacific is deliberate, and we simultaneously acknowledge that Pasifika scholars in particular choose to use these terms in different ways. Hau'ofa (2008), for example, prefers the term Oceania "above all others" (p. 52) to describe the Moana, while Suaalii-Sauni's (2017) preference for the term Pasifika lies in the way in which the word "brings alive to the senses" the familiar sounds that Moana languages share (p. 163). Our views align with Naepi (2019), who explains that her use of the term Pasifika is "not about homogeneity but about bringing our people together to better serve our own interests in a globalized world" (p. 221). Furthermore, Māhina (2010) argues that Moana is "the ethnographic indigenous-based, internally mediated name" rather than the "problematic foreign-led, externally imposed label Oceania or for that matter Pacific" (p. 168). Continued discussion amongst and between Māori and Pasifika scholars around the purpose and use of our terms is yet another vital aspect of us coming together.

$\mathrm{V} \overline{\mathrm{a}}-\mathrm{k} \overline{\mathrm{a}}$ methodology is our contribution to the exciting literature wave of Indigenous methodologies that have emerged from the Moana (see Campbell, 2019; Fa'avae, 2016; Hau'ofa, 2008; Johansson-Fua, 2014; Lee, 2008; L. T. Smith, 1999; Te Ava \& Page, 2018). We choose here to use the term Moana or Moana-nui-a-Kiwa to shift the focus from a Western-applied naming of the "Pacific Ocean" and bring forth the familiar sounds of our Moana languages. More specifically, the act of creatively binding language is central to our assertion of Vā-kā methodology as we lash together two terms- - vā and kā-from two (or more) sets of Moana languages to demonstrate a combined Māori and Pasifika researcher approach.

Indigenous and Moana research methodologies such as $V \bar{a}-k \bar{a}$ insist that researchers articulate their relationship(s) in and to the research. What or who should be included or excluded in the work and how data are interpreted, analysed and presented, and for what purpose, means that researcher positionality is a critical Indigenous methodological consideration (Chilisa, 2012; L. T. Smith, 1999). The notion of vā reinforces how groups and communities are valued over the individual (Autagavaia, 2001; Taufe'ulungaki, 2004). More importantly, it reinforces how in relation to others the integrity of the self is shaped and realised: "The self does not exist alone, and the Samoan individual does not survive in isolation" 
(Autagavaia, 2001, p. 59). In the context of higher education research, it is also a guiding code of conduct that reminds us to be mindful of our intentions and our actions. Vā-kā methodology places importance on positionality and relationships, paying attention to the forming, maintaining and nurturing of relationships with and between researchers, and therefore we introduce ourselves at the outset.

The second author is a Tongan-born woman from the islands of Falevai Vava'u, Tongaleleka $\mathrm{Ha}$ 'apai and 'Atataa. She is a lecturer and academic developer at the University of Auckland. I am a Māori woman from the Te Rarawa, Ngā Puhi and Te Ati Awa iwi of Aotearoa New Zealand. A te reo Māori teacher and Kaupapa Māori researcher, my interests are in decolonial education, arts research, Kaupapa Māori methodologies and higher education. Emerging from our experience of working together as a Māori woman and a Tongan woman, 'Ema and I are keenly interested in how Māori and Pasifika academics can further enhance our Moana research relationships to create change in the tertiary sector.

We begin by introducing the "problem" that exists with a Māori and Pasifika research collaboration, locating our theorisation of Vā-kā methodology in the context of the He Vaka Moana research fellowship. Next, we scan the ocean/ literature-scape of Indigenous and Moana methodologies as the theoretical foundations of Vā-kā methodology, unpacking the language of vā and kā, which we suggest can be lashed together to create exciting potential research relationships from old Moana ties.

\section{Naming and claiming the problem}

Put simply, Māori and Pasifika researchers in higher education do not talk enough. Our bodies of theory and research have necessarily developed their own distinct approaches that emerge from, and are in response to, both the different and the similar issues that our diverse groups encounter. Kaupapa Māori theory, for example, emerged as a radical response from Māori academics in the 1990s to create space for Māori-centric thinking and research in the academy, or what Māori scholar Leonie Pihama (2001) calls a "culturally defined theoretical space" (p. 77). Articulated by a number of prominent Māori academics (Henry \& Pene, 2001; Irwin, 1994; Lee, 2008; Pihama, 2001; G. H. Smith, 2003; L. T. Smith, 1999), Kaupapa Māori theory places Māori language, values and beliefs at its centre, encouraging Māori researchers to look to their own sets of knowledge to develop approaches to research. From this theoretical foundation, robust and innovative Kaupapa Māori research has for 30 years tackled an array of research problems across multidisciplinary fields both in Aotearoa New Zealand and abroad.

Similarly, Pasifika theorists have developed a number of innovative research approaches, including Kakala (Johansson-Fua, 2014; Thaman, 1993), Talanoa (Fa'avae, 2016; Vaioleti, 2006), Tivaevae (Maua-Hodges, 2001), the Fijian Vanua Research Framework (Nabobo-Baba, 2006) and Fa'afaletui (Tamasese et al., 1997), to name a few. In addition, we acknowledge and lean on the work of Pacific scholars such as Albert Wendt, Epeli Hau'ofa, David Gegeo and Manulani Meyer as voyaging pioneers who have theorised, contested and foregrounded Indigenous knowledges and research methods in this space.

It could be argued that Māori and Pasifika people have been socially set against each other through systemic racism and societal structures that have discouraged the forging of Moana relationships, forcing us to compare and contrast ourselves rather than collaborating and collectivising (Anae et al., 2015; Harris, 2004; Suaalii-Sauni, 2017). Airini et al. (2010), for example, discuss the need for Pacific researchers to teu le vā-or nurture relationships-with tāngata whenua and vice versa in order to grow Māori and Pasifika research space. Imagine for a moment the potential disruption to the monocultural social and political status quo in Aotearoa New Zealand that would result from a strengthened political, social and economic alliance of Māori and Pasifika energy.

There are examples of Māori and Pasifika collaboration in our broader Indigenous contexts-the great collaborative advances made in ocean-going sea voyaging (Evans, 2015; Howe, 2006) developed through Māori, Hawaiian, Tahitian and many other Pacific nations reclaiming and revitalising knowledge of seafaring vessels. Another example is in the field of arts research, where forums such as the Pacific Arts Festival draw together artists from all four winds of the Moana to collaborate. Yet Māori and Pasifika theoretical collaboration in education, particularly higher education, in Aotearoa New Zealand is lagging behind the fleet.

A recent example of Māori and Pasifika research in conversation with each other is a book chapter written by Samoan criminologist Tamasailau Suaalii-Sauni (2017), who writes about a direct relationship between the vā and Kaupapa Māori. She discusses the need for "a more deliberate conversation between Pasifika researchers about 
how to go about engaging with Māori peoples and with research tools, concepts, and theories, including Kaupapa Māori” (p. 162). We align with Suaalii-Sauni's (2017) assertion that the time is ripe for Māori and Pasifika research to collaborate in ways that enhance our individual and wider collective agenda. Here we recall Graham Smith's response on the issue of Pasifika working together with Māori particularly in engaging with Kaupapa Māori and methodologies: "It is about people, it is about relationships" (as cited in Naepi, 2015). There is a need for increased and productive conversations between Māori and Pasifika researchers, our concepts and cultural frameworks. Vā-kā methodology offers a way to facilitate this kind of purposeful and deliberate conversation.

It is important to reinforce here the complex and heterogeneous nature of Māori and Pasifika identities. Resisting the tendency to homogenise identities and/or re-entrench boundaries between these groups, instead we seek to ignite the relational space between by theorising an approach to encourage Māori and Pasifika researchers to come together, each bringing with them, and maintaining, their sovereign ways of being to forward collaborative research that supports our wider, multiple and complex agendas.

\section{He Vaka Moana research fellowship}

Vā-kā methodology emerged from our experience as a Māori woman and a Tongan woman coleading a one-year research fellowship on Māori and Pasifika student "success" at the University of Auckland. The fellowship offered a 0.2 time release for one year to nine academic and professional staff who each developed a strengths-based teaching and learning research project around Māori and Pasifika student success within their faculty. Five of these projects are presented in this special issue. A mixed "crew", the nine fellows consisted of three Māori, three Pasifika and three Pākehā across all but one of the university faculties.

The involvement of non-Māori and nonPasifika research allies in a tertiary context is necessary-and in the context of this fellowship was insisted upon by the institution. At the University of Auckland, Māori comprise 5.9\% and Pasifika $2.7 \%$ of academic staff (University of Auckland, 2018, p. 8), which, while low, is slightly above the national averages of $5 \%$ Māori and 1.7\% Pasifika (McAllister et al., 2019; Naepi, 2019). Two recently published articles, "Why Isn't My Professor Māori?” (McAllister et al., 2019) and "Why Isn't My Professor Pasifika?" (Naepi, 2019) work powerfully in tandem to highlight the “active structural underserving” (Naepi, 2019, p. 221) and exclusion of Māori and Pasifika from academic roles in New Zealand universities. For example, despite a $26 \%$ increase of Māori doctoral students between 2009 and 2016 (McAllister et al., 2019, p. 237) and broadly similar "equity and diversity" staffing policies that espouse the recruitment and retention of Māori and Pasifika staff, Pākehā academic staff remain the dominant ethnicity, accounting for between $56 \%$ and $83 \%$ of academic staff in our universities.

The tertiary sector continues to ignore issues of systemic racism and fails to prioritise the development, hiring, retention and promotion of Māori and Pasifika academics (McAllister et al., 2019; Naepi, 2019). Naepi (2019) argues that highlighting the critically low numbers of Pasifika academics is a powerful exercise in change to "hold government and universities accountable for their inaction against structural racism" (p. 220). Until the tertiary sector actively addresses these staffing inequities, our growing student body of Māori and Pasifika students will problematically continue to rely on the "goodwill" and cultural capabilities of non-Māori and non-Pasifika teaching staff to work with us in this space. Critical conversations must continue amongst Māori and Pasifika, and with non-Māori and non-Pasifika, about how to best serve the needs of our students in ways that neither appropriate cultural knowledge nor continue to homogenise cultural groups and perpetuate racial inequities in education.

Forwarding Vā-kā methodology does not set out to exclude non-Māori and non-Pasifika research allies or ideas. In the context of the $\mathrm{He}$ Vaka Moana research fellowship, strong and enduring relationships between Indigenous and non-Indigenous fellows were forged as we learned about our own strengths and weaknesses, abilities and fragilities, through time spent developing and consequently igniting the vā between us. This relationship is particularly crucial given the low number of Māori and Pasifika staff across the higher education sector. As with most relationships where diverse entities are drawn together, the fellowship was not devoid of friction and frustration as different sets of assumptions and cultural capabilities occasionally prompted tense debate and disagreement. As insecurities and anxieties were revealed, emotions were sometimes piqued but appeared to be mediated through, and because of, the time and energy spent in developing the vā within the fellowship.

The emotive issues of Indigenous and nonIndigenous collaboration, in research and beyond, 
are complex. In the fellowship, for example, a non-Indigenous fellow may have been a senior academic with a great deal of research experience and expertise but little knowledge of Māori and Pasifika culture. Conversely, some of the Indigenous fellows who brought in-depth cultural expertise and knowledge may have had less experience in aspects of research such as publication or ethics. One example was what we might name in Te Ao Māori as kanohi kitea, that is, the "seen face", a phrase used to describe a person who always shows up or takes the time to be present as a demonstration of commitment to the group. Those who appeared at He Vaka meetings irregularly or sometimes not at all were commented on as not contributing to or nurturing the vā. The fellowship demonstrated that nurturing and maintaining of the wā (space) and vā (relational space) through being present and actively involved was critical and expected.

There are many and varied ways that researchers, both Indigenous and non-Indigenous, come together to collaborate in research (and beyond). We encourage other cultural research collaborations to identify their connections to one another and to theorise their own language, knowledges and ways of being to develop transforming research methodologies. How, for example, might Māori and Aboriginal researchers work together, or perhaps Tongan and Hawaiian doctoral students, drawing on their common and intersecting knowledges? Here we privilege the powerful and unique relational space-the wā or vā-between Māori and Pasifika researchers by lashing together a Pasifika word and a Māori word to theorise our experience and offer a way to further develop purposeful and transforming research journeys. Having named our fellowship He Vaka Moana, 'Ema's cultural and language knowledge provided a Tongan proverb that gave us our conceptual framework.

\section{Pikipiki hama kae vaevae manava}

The fellowship drew its strength from the Tongan proverb "pikipiki hama kae vaevae manava" (see Wolfgramm-Foliaki \& Smith, 2020). Pikipiki hama means to stick, bind or link strongly to the outrigger of a vaka moana (ocean-going canoe). Vaevae means to give or share, and manava (similar to the word manawa in Māori) is a deeply complex, core term in Pasifika expression meaning the heart, centre, womb or breath (Efi, 2003). This proverb speaks to the ancient Moana practice of lashing together the outriggers of canoes whilst at sea, a practice that enabled ocean travellers to swap resources, exchange information about their travels and experiences, weather and ocean conditions, and sometimes even exchange crew members before unlashing and continuing on their journey.

Our theorisation of pikipiki hama in this research fellowship resists the tired and problematic education trope of "we are all in this vaka/ waka together" or "let's all paddle this vaka/ waka together" to denote an uncritical and overly romantic idea of unity or coming together of ideas and often cultural ways of being. Such rhetoric raises the question of whose vaka/waka am I being asked/coerced into, and are we really paddling in the same direction, with the same purpose and with a mutually agreed destination? Or indeed is getting in the "one vaka/waka" a further exercise in cultural assimilation? Instead, we suggest that in coming together each vessel's rangatiratanga or cultural sovereignty is better maintained and better facilitates a sharing of power and choice around when, with whom and for how long vessels may choose to be lashed to another. We are interested in igniting the vā to activate and give energy to the potentiality that exists in the space that binds and feeds the space between Māori and Pasifika in a research context.

Pikipiki hama was theorised and enacted in our research fellowship as a way to bring people, projects, ideas and identities together that encouraged each entity to retain their rangatiratanga while actively encouraging and creating space for productive discussion, critique and learning to take place. One of the research fellows (see Fonua, 2020) established regular monthly talanoa (a Tongan process of sharing time space and discussion) for academic and professional staff to meet and discuss important pedagogical issues in relationship to each other. Amongst the fellows, pikipiki hama was enacted through monthly wānanga and regular hui to come together both socially and more methodically to write, share ideas, talk through research issues and consider the impact and implications of our collective research agenda. Importantly, our intention was to enact and enable the forming and enriching of relationships-igniting the vā then fanning the flames-to create spaces that are all too rare for Māori and Pasifika academics in higher education.

The why, or reason to take up Vā-kà as a research approach, is straightforward: to work productively together to support change for our people. The how is far more complex. The practical applications to chart a course using Vā-kā methodology are as vast as the Moana itself, and 
while practical examples such as Talanoa mentioned above are useful (see the five articles by He Vaka Moana fellows in this issue), we do not attempt here to provide a "how to do Vā-kā methodology" — such an attempt fails to recognise the heterogeneous complexities of varied and different contexts, people, capabilities and aspirations. Instead, we argue for why enhanced Māori and Pasifika research relationships are vital and encourage others to consider their own how in their own contexts based on the key tenets of productive Māori and Pasifika collaboration, sovereignty and transformation that Vā-kā methodology forwards.

\section{Theorising a Moana methodology}

As Moana people we have always been theoretical, developing our own methodologies or ways of approaching problems. These methodical sets of knowledge have for centuries supported great advances, enabling Indigenous communities around the world to explore, adapt and advance our technologies (Chilisa, 2012; Efi, 2003; Hau'ofa, 2008; Kovach, 2009; Meleiseā, 1987; Pihama, 2001; L. T. Smith, 1999; Thaman, 1998, 2000). Yet methodology in our more recent history has been captured and claimed by the academy, nudging our ancient ways of research to the academic margins. Here we turn to our own Māori and Pasifika scholars who have chartered similar courses through the sea of literature, connecting islands of theory that create and reinforce our whakapapa links.

Eminent Māori scholar Linda Tuhiwai Smith's seminal work Decolonizing Methodologies (1999) strongly advocates for re-framing and re-claiming methodologies as a critical element of a strategic Indigenous research agenda. Smith discusses the tides or states of survival, recovery, development and self-determination that intersect with those of decolonisation, healing, transformation and mobilisation, none of which are linear; nor are they goals or ends in themselves. Instead, they are "processes which connect, inform and clarify the tensions between the local, the regional and the global ... processes which can be incorporated into practices and methodologies" (L. T. Smith, p. 116). Indigenous methodologies have evolved to fit a contemporary reality shaped by the struggle to resist the assault of colonisation through projects of cultural reclamation. Educationalist and academic Leah Abayao (2006) discusses Indigenous methodology as that which is "acquired over generations by communities as they interact with the environment ... exploring indigenous technological knowledge and knowledge transmission systems, and recasting the potentialities they represent" (p. 180).

Kaupapa Māori scholar Leonie Pihama (2001) reminds us that theory and methodology did not arrive with the coloniser. Rather, Indigenous peoples have for centuries engaged in their own forms of methodological research to test theories and advance thinking:

As Māori we have a history of investigation. It is an ancient history of exploration, of navigation, not solely in the physical domain, but in ways that reach throughout the many dimensions of Te Ao Māori. These are all forms of research, they are all ways within which our people have developed knowledge and have located ourselves in the wider world. (Pihama, 2001, p. 47)

Consider, for example, the sophisticated navigational systems developed by our early ancestral sea voyagers that enabled them to criss-cross the Moana, technologies later regarded as superior to those of the Western world at the time (Evans, 2015). Navigational methods and methodologies such as these required high level theorisation, research, development and testing in order for return voyages across vast expanses of ocean to succeed. Pacific navigation is known to involve methodical systems that enabled Moana people to travel and successfully populate the countless islands in the region. Turnbull (1994) points out that Pacific navigation is the most outstanding example of a knowledge system that can be compared with Western technoscience. A more recent development is the New Zealand Ministry of Pacific Peoples' (2017) new Pacific policy analysis tool titled Kapasa. The word kapasa refers to the ancient Polynesian compass that was used by our ancestors to help them navigate the vast Pacific Ocean. As a policy tool it provides guidance for how Pacific perspectives and worldviews can be identified and included in wider policy.

Methodology, as an element of research, is an immutable aspect of academic scholarship. It refers to the concepts and theories that frame the way research is conducted, that is, the knowledges and influences that underpin research as a process for creating "new" knowledge. Over the last 40 years, Indigenous research methodologies within an academic context have taken up critical Indigenous theories (Kovach, 2005, 2009; L. T. Smith, 1999) that seek to re-claim, re-frame and re-present the lived realities of Indigenous peoples. Rather than accept a Western academic 
definition of methodology, we are encouraged by other Indigenous researchers to look to our own "ways of being" in the world based on our own methodologies to create new knowledges that will serve us in our current lived realities. By re-claiming methodology as an aspect of being Indigenous that has for centuries served our people and allowed them to flourish, we are re-framing how methodology can be viewed both within academic paradigms and beyond.

Importantly, here we argue that methodology is a lived experience, a praxis if you will, of lashing together the theory and practice-the thinking and doing. We argue that Vā-kā methodology cannot simply be understood from a distance but must be enacted, embodied and experienced. Vā-kā methodology insists upon an understanding of the who I am that I bring to this research relationship, the language, the identity, the intent and the contribution that "I" offer to igniting the space. Important to note here is that in line with vā, the "I" or "self" is viewed in relation to others or the collective (Mila-Schaaf, 2006).

\section{The vā and the kā}

$\mathrm{V} \overline{\mathrm{a}}$ has been theorised, embodied and enacted in research in a number of powerful ways by Pasifika scholars (see Anae, 2010; Autagavaia, 2001; Ka'ili, 2017; Māhina, 2010; Suaalii-Sauni, 2017; Taufe'ulungaki, 2001). Samoan criminologist Suaalii-Sauni (2017) describes the vā as "a central organizing principle in many Pasifika cultures [that] governs all inter-personal, inter-group, and sacred/secular relations and is intimately connected to a Pasifika sense of self or identity" (p. 163). In a Ministry of Education report on relationships across research and policy, Airini et al. (2010) state:

Va-or vā, va'a, vaha-can be loosely translated as a spatial way of conceiving the secular and spiritual dimensions of relationships and relational order, that facilitates both personal and collective well-being, and teu le vā as the valuing, nurturing and looking after of these relationships to achieve optimal outcomes for all stakeholders. (p. 10)

Tēvita O. Ka'ili (2005) offers a Tongan scholar's perspective on Moana notions of vā. He describes vā as both social relationships and space (p. 90) and tauhi vā as the Tongan value and practice of "keeping good relations . . . to tend, or to nurture" (p. 92). He adds that "the performance of tauhi vā is often etched forever in the memories of people involved in the process" (p. 93). Samoan scholar
Melani Anae (2010) takes vā one step further, theorising a Samoan concept of teu le vā or the action of nurturing the vā, that is "to look after the space". She states that "by its very nature teu le vā has multi-relational, situational and spiritual references" (p. 13). Significantly, Anae's theory highlights the unique role of the vā within a MāoriPasifika research relationship. She notes that the importance of "nurturing the vā and spaces that have already been created by tāngata whenua" was a means of acknowledging the special status of tāngata whenua in Aotearoa New Zealand (Anae, 2010, p. 17).

In the Māori language, definitions of wā (the Māori derivative of vā) are relevant to our theorisation. Wā is defined in A Dictionary of the Maori Language (Williams, 1997) as "definite space, time” (p. 472). The Reed Dictionary of Modern Māori (Ryan, 1995), meanwhile, defines wā as “an opportunity” (p. 330). The term wā appears in a number of Māori words such as wāhi, which means space to move, wānanga, as a learning or knowledge creation space, and wātea, to be clear of thought or free of burden. Linda Tuhiwai Smith (1999) discusses how the concepts of time and space are particularly significant to Indigenous peoples, as well as the importance of reclaiming these ideas in a decolonising research agenda. "Space", she writes, "is often viewed in Western thinking as being static or divorced from time" (p. 52). In many Indigenous languages there is no clear distinction between the notions of time and space; in the Māori language, for example, the word for time and space-wā-is one and the same.

The Māori term for kā (with a macron) means to make fire, to be lighted or ignited and allow to burn, and, interestingly, ka (without a macron) also lends itself to our idea in that it means the commencement of a new action or condition (Williams, 1997, p. 81). By drawing on our knowledge of our respective languages to lash together a Māori term with a Pasifika term, we seek to enact Vā-kā, the igniting of the relationships between Māori and Pasifika researchers, of time and space, of interests and reciprocal ties that have for generations nurtured and bound us as Moana peoples. It is important to reiterate here that underpinning vā and wā is a commitment to ensure that the vā is nurtured and maintained, not just for research purposes but in all aspects of how we as Māori and Pasifika academics relate to one another, placing good relationships at its centre. 


\section{The vaka}

The terms vaka (Tongan, Samoan), wa'a (Hawaiian) and waka (Māori) can be broadly defined as a canoe, vessel, vehicle or conveyance, of which there are many sub-types, such as waka taua (war canoes), a waka ama (outrigger canoes) or, in the present context, waka moana or ocean-going vessels (Evans, 2015). A resurgence of interest in ocean voyaging across the Moana has generated a sea swell of literature in the areas of vaka moana and sea navigation (Evans, 2015; Howe, 2006), reclaiming a rich source of maritime knowledge once in danger of being lost. Vaka have for generations served as powerful conceptual symbols within Te Moana-nui-a-Kiwa. For example, in Vanuatu:

The tree symbolizes rootedness in culture, while the canoe stands for movement along sea routes that connect people of different island locations. The canoe is history-the working out of relationships established through travel and movement of materials from one island to another. One may extend this metaphor to include present-day connections between Oceania and the surrounding continental landmasses and cultures. (Hau'ofa, 2008, p. 81)

More recently, vaka and its associated ocean terminology have been used as conceptual frameworks for arts practices (Looser, 2015) and in areas such as leadership (Spiller et al., 2015), to name just a few. In higher education, the idea of vaka moana has been used in powerful ways to bring students together in relationship and to encourage positive learning experiences (Teaiwa, 1994, 2017). In Pacific Studies at the University of Auckland, for example, Vaka Moana is a successful academic advancement programme grounded in Moana values to nurture the relationships between students and tutors.

\section{Vā-kā within wider Indigenous research methodologies}

We are encouraged to theorise Vā-kā methodology thanks to the powerful emergence of Indigenous research methodologies in the 1970s as part of a wider global movement of resistance and reclamation (see Chilisa, 2012; Kovach, 2005, 2009; Thaman, 1993, 2000). Indigenous researchers sought to re-centre Indigenous beliefs and privilege Indigenous knowledge systems in an effort to "decolonize dominant research methodologies" (Chilisa, 2012, p. 31) by theorising Indigenous approaches as valid, robust and rigorous forms of inquiry. Indigenous methodologies are decolonising and work to create legitimate academic space where the Indigenous disenfranchised and dispossessed, can re-claim, re-store and re-present-seeing with their own eyes their history of colonisation (Chilisa, 2012).

Indigenous research methodologies create space in the Western academy to view and conduct research through an Indigenous lens. Indigenous scholars such as Irwin (1994), Kovach (2009), Lee (2008), Maua-Hodges (2001), Nabobo-Baba (2008), Pihama (2001), Pohatu (2011), Royal (2011), Suaalii-Sauni (2011), L. T. Smith (1999), Thaman (1993, 2000) and Vaioleti (2006), amongst others, have encouraged other Indigenous researchers to look to our own systems of knowledge to develop methodologies to investigate our own problems and make visible the ways we see the world. Often activated by a politics of resistance, Indigenous researchers are using our own approaches to speak back to Western research practices that marginalise our ways of being. Instead, Indigenous methodologies work to re-centre, reclaim and re-present Indigenous knowledge as a valid and robust approach to research and, more importantly, as capable of contributing to positive transformations for Indigenous people.

\section{Conclusion}

Māori and Pasifika researchers must talk more. It is vital in our view that we create the wā and nurture the vā to come together in ways that create positive transformative change for our complex and diverse communities. Rather than further homogenise our broad decolonising agenda, we seek to ignite the space between us to offer ways to talk and share ideas. Theorising Vā-kā methodology hones in on a particular set of relationships, that is, the relationship between Māori and Pasifika researchers. Until the critically low numbers of Māori and Pasifika academics is addressed, it remains necessary to pikipiki hama with non-Indigenous allies capable of working within Indigenous Moana paradigms.

Theorising methodologies that examine deeply the language, beliefs and ways of being held within Māori and Pasifika sets of knowledge is critical to address issues that we face in our contemporary lived realities from within our ways of knowing, being and doing. Enabled and emboldened by Indigenous scholars who have, and continue to, chart the academic seascape, we forward Vā-kā methodology to encourage Indigenous Moana scholars to look to our own sets of ideas, understandings, knowledge, language and ways of being to theorise and seek transforming solutions. While Moana methodologies are becoming more visible 
in academia, our methodologies are still held to the margins within Western (dominant) scholarship. Vā-kā is our contribution of one more "vaka to the fleet" of Indigenous and, more specifically, Moana methodology as an encouragement to new and emerging Moana researchers, as well as our experienced colleagues, to continue to collaborate, connect, ignite and transform.

Importantly, Vā-kā methodology charts a course into rarely traversed waters, that is, the body of water/wai /vai that both connects and separates Māori and Pasifika research(ers). While the same body of water nurtures and sustains, and sometimes batters and subsumes us, it is Te Moana-nui-a-Kiwa, the Pacific Ocean, that ultimately connects us as Moana peoples, and it is to the Moana that we turn to once again ignite and join the space between us.

\section{Glossary}

\begin{tabular}{|c|c|}
\hline Fa'afaletui & Samoan research methodology \\
\hline He Vaka Moana & Oceanic Research Project \\
\hline hui & meetings, gatherings \\
\hline $\mathrm{a}$ & commencing an action \\
\hline $\bar{a}$ & ignite, fire \\
\hline Kakala & Tongan research methodology \\
\hline kanohi kitea & the seen face, being present \\
\hline kapasa & ancient Polynesian compass \\
\hline Kaupapa Māori & Māori research methodology \\
\hline Māori & $\begin{array}{l}\text { Indigenous peoples of Aotearoa } \\
\text { New Zealand }\end{array}$ \\
\hline moana & ocean \\
\hline Pasifika & peoples of the Pacific Ocean \\
\hline $\begin{array}{l}\text { pikipiki hama } \\
\text { kae vaevae } \\
\text { manava }\end{array}$ & $\begin{array}{l}\text { to bind of lash together the } \\
\text { outrigger of a vaka moana and } \\
\text { share resources }\end{array}$ \\
\hline rangatiratanga & cultural sovereignty \\
\hline talanoa & $\begin{array}{l}\text { sharing stories, creating dialogue } \\
\text { in an inclusive, receptive space }\end{array}$ \\
\hline Talanoa & Tongan research methodology \\
\hline tāngata whenua & $\begin{array}{l}\text { the people of the land, Indigenous } \\
\text { Māori }\end{array}$ \\
\hline Te Ao Māori & the Māori world \\
\hline $\begin{array}{l}\text { Te Moana-nui- } \\
\text { a-Kiwa }\end{array}$ & the Pacific Ocean \\
\hline te reo Māori & Māori language \\
\hline teu le vā & maintaining the relational space \\
\hline Tivaevae & Cook Islands research framework \\
\hline vā & relational space between \\
\hline$v^{6} a$ & seafaring vessel \\
\hline vaka & seafaring vessel \\
\hline$k \bar{a}$ & genous methodology \\
\hline
\end{tabular}

$\begin{array}{ll}\text { wā } & \text { time } \\ \text { wāhi } & \text { place } \\ \text { wai/vai } & \text { water } \\ \text { waka } & \text { seafaring vessel } \\ \text { waka ama } & \text { outrigger vessel } \\ \text { waka moana } & \text { seafaring vessel } \\ \text { waka taua } & \text { war vessel } \\ \text { wānanga } & \text { to meet and discuss, traditional } \\ & \text { learning space } \\ \text { wātea } & \text { to be free } \\ \text { whakapapa } & \text { genealogy, ancestry, history } \\ \text { whānau } & \text { family beyond the nuclear } \\ & \text { grouping }\end{array}$

\section{References}

Abayao, L. E. (2006). Articulating Indigenous people's culture in education. In I. Abu-Saad \& D. Champagne (Eds.), Indigenous education and empowerment: International perspectives (pp. 179_ 187). AltaMira Press.

Airini, A., Anae, M., \& Mila-Schaaf, K. (2010). Teu Le Va: Relationships across research and policy in Pasifika education. Ministry of Education.

Anae, M. (1997). Towards a NZ-born Samoan Identity: Some reflections on "labels". Pacific Health Dialog, 4(2), 128-137.

Anae, M. (2010). Research for better Pacific schooling in New Zealand: Teu Le $\mathrm{Va}$-a Samoan perspective. MAI Review, (1), 1-24.

Anae, M., Tamu, L., \& Iuli, L. (2015). Polynesian Panthers: Pacific protest and affirmative action in Aotearoa New Zealand 1971-1981. Huia.

Autagavaia, M. (2001). Social work with Pacific Island communities. In M. Connolly (Ed.), New Zealand social work: Contexts and practice (pp. 72-84). Oxford University Press.

Campbell, D. (2019). Ngā kura a Hineteiwaiwa: The embodiment of Mana Wabine in Māori fibre arts [Doctoral thesis, University of Waikato]. Research Commons. https://hdl.handle.net/10289/12583

Chilisa, B. (2012). Indigenous research methodologies. SAGE Publications.

Efi, T. A. T. T. T. (2003). In search of meaning, nuance and metaphor in social policy. Social Policy Journal of New Zealand, 20, 49-63.

Evans, J. (2015). Heke-nuku-mai-ngā-iwi Busby: Not here by chance. Huia Publishers.

Fa'avae, D. (2016). Tatala 'a e Koloa 'o e To'utangata Tonga i Aotearoa mo Tonga: The intergenerational educational experiences of Tongan males in New Zealand and Tonga [Doctoral thesis, University of Auckland]. ResearchSpace. http://hdl.handle. net/2292/32183

Fishman, J. (1996). What do you lose when you lose your language? In G. Cantoni (Ed.), Stabilizing indigenous languages (pp. 80-91). University of Arizona Press.

Fonua, S. (2020). 'Lalanga ha kaha'u monu'ia: Helping science educators to embed Indigenous knowledge, 
values and cultures in their courses for Māori and Pacific science student success. Mai Journal, 9(1), 49-58.

Harlow, R. (2005). Covert attitudes to Māori. International Journal Social Language, 172, 133147. http://doi.org/fqg4xs

Harris, A. (2004). Hikoi: Forty years of Māori protest. Huia Publishers.

Hau'ofa, E. (2008). We are the ocean: Selected works. University of Hawai'i Press.

Henry, E., \& Pene, H. (2001). Kaupapa Maori: Locating Indigenous ontology, epistemology and methodology in the academy. Organization, 8(2), 234-242. http://doi.org/djbdkq

Howe, K. R., \& Auckland War Memorial Museum. (2006). Vaka moana: Voyages of the ancestors: The discovery and settlement of the Pacific. David Bateman.

Irwin, K. (1994). Mātauranga. In A. Brown (Ed.), Mana Wāhine: Women who show the way (pp. 74-81). Reed Publishing.

Johansson-Fua, S. (2014). Kakala research framework: A garland in celebration of a decade of rethinking education. In M. Otunuku, U. Nabobo-Baba, \& S. Johansson-Fua (Eds.), Of waves, winds and wonderful things: A decade of rethinking Pacific education (pp. 50-60). University of the South Pacific Press.

Ka'ili, T. O. (2005). Tauhi Vā: Nurturing Tongan sociospatial ties in Maui and beyond. The Contemporary Pacific, 17(1), 83-114. http://doi.org/cxf7x9

Kovach, M. (2005). Emerging from the margins: Indigenous methodologies. In L. Brown \& S. Strega (Eds.), Research as resistance: Critical, indigenous and anti-oppressive approaches (pp. 19-36). Canadian Scholars' Press/Women's Press.

Kovach, M. (2009). Indigenous methodologies: Characteristics, conversations and contexts. University of Toronto Press.

Lee, J. (2008). Ako: Pūrākau of Māori teachers' work in secondary schools [Unpublished doctoral thesis]. University of Auckland, Auckland, New Zealand.

Looser, D. (2015). Oceanic imaginaries and waterworlds: Vaka moana on the sea and stage. Theatre Journal, 67(3), 465-486. http://doi.org/dn7s

Māhina, H. 'O. (2010). Tā, vā and moana: Temporality, spatiality, and indigeneity. Pacific Studies, 33(2-3), 168-202.

Maua-Hodges, T. (2001). The Tivaevae model: Designing and making of Tivaevae as the framework for research [Unpublished manuscript]. Victoria University of Wellington and Wellington College of Education, Wellington, New Zealand.

McAllister, T. G., Kidman, J., Rowley, O., \& Theodore, R. (2019). Why isn't my professor Māori? MAI Journal, 8(2), 235-249.

Meleiseā, M. (1987). The making of modern Samoa. University of the South Pacific, Institute of Pacific Studies.

Mila-Schaaf, K. (2006). Vā-centred social work: Possibilities for a Pacific approach to social work practice. Social Work Review, 18(1), 8-13.

Ministry of Pacific Peoples. (2017). Kapasa: The Pacific policy analysis tool. https://www.mpp.govt.nz/ assets/Uploads/2-Kapasa2017-A4-Pages-WEB4. pdf

Nabobo-Baba, U. (2006). Knowing and learning: An indigenous Fijian approach. Institute of Pacific Studies Publications.

Naepi, S. (2015). Navigating the currents of Kaupapa Māori and Pan-Pacific research methodologies in Aotearoa New Zealand. MAI Journal, 4(1), 71-84.

Naepi, S. (2019). Why isn't my professor Pasifika? MAI Journal, 8(2), 219-234.

O’Regan, H. (2011). "I've lost my voice": A look at the role of Māori language competency and accessibility in the lives of our tamariki in compulsory education. In P. Whitinui (Ed.), Kia tangi te tìtī: Permission to speak (pp. 30-45). NZCER Press.

Pihama, L. (2001). Tihei mauri ora. Honouring our voices: Mana Wāhine as a Kaupapa Māori theoretical framework [Doctoral thesis, University of Auckland]. ResearchSpace. http://hdl.handle. net/2292/1119

Pohatu, T. W. (2011). Mauri: Rethinking human wellbeing. MAI Review, (3), 1-12.

Royal, C. T. A. (2011). Wānanga: The creative potential of mātauranga Māori. Mauriora-ki-te-Ao/Living Universe.

Ryan, P. M. (1995). The Reed dictionary of modern Māori. Reed Publishing.

Smith, G. H. (2003, December). Kaupapa Maori theory: Theorizing Indigenous transformation of education and schooling [Paper presented at the Kaupapa Maori Symposium-NZARE/AARE Joint Conference, Auckland, New Zealand].

Smith, L. T. (1999). Decolonizing methodologies: Research and indigenous peoples. University of Otago Press.

Spiller, C., Barclay-Kerr, H., \& Panoho, J. (2015). Wayfinding leadership: Groundbreaking wisdom for developing leaders. Huia Publishers.

Suaalii-Sauni, T. (2011). "It's in your bones!” Samoan custom and discourses of certainty. Yearbook of New Zealand Jurisprudence, 14, 70-88.

Suaalii-Sauni, T. (2017). The va and Kaupapa Māori. In T. K. Hoskins \& A. Jones (Eds.), Critical conversations in Kaupapa Māori (pp. 161-178). Huia Publishers.

Tamasese, K., Peteru, C., \& Waldegrave, C. (1997). Ole taeao afua: The new morning: A qualitative investigation into Samoan perspectives on mental bealth and culturally appropriate services. The Family Centre.

Taufe'ulungaki, 'A. (2004). Fonua: Reclaiming Pacific communities in Aotearoa. In Lotu Moui: Keynote speeches (pp. 1-6). Counties Manukau District Health Board.

Teaiwa, T. (1994). Preparation for deep learning: A reflection on "teaching" Pacific Studies in the Pacific. Journal of Pacific History, 46(2), 214-220. http://doi.org/dbck28

Teaiwa, T. (2017). Charting Pacific (Studies) waters: Evidence of teaching and learning. The Contemporary Pacific, 29(2), 265-282. http://doi. org/gdxrdt 
Te Ava, A., \& Page, A. (2018). How the tivaevae model can be used as an Indigenous methodology in Cook Islands education settings. Australian Journal of Indigenous Education, 1-7. http://doi.org/c6mf

Thaman, K. H. (1993). Culture and the curriculum in the South Pacific. Comparative Education, 29(3), 249-260. http://doi.org/dzjcwv

Thaman, K. H. (1997). Reclaiming a place: Towards a Pacific concept of education for cultural development. Journal of the Polynesian Society, 106(2), 119-130.

Thaman, K. H. (1998, March 30-April 3). Learning to be: A perspective from the Pacific Islands [Keynote address]. UNESCO Conference on Education for the 21st Century in the Asia/Pacific Region, Melbourne, Australia.

Thaman, K. H. (2000). Towards a new pedagogy: Pacific cultures in higher education. In G. P. Teasdale \& Z. Ma Rhea (Eds.), Local knowledge and wisdom in higher education (pp. 43-50). Pergamon.

Turnbull, D. (1994). Comparing knowledge systems: Pacific navigation and Western science. In
J. Morrison, P. Gerarthy \& L. Crowl (Eds.), Science of Pacific Island people: Vol.1. Ocean and Coastal Studies (pp. 129-144). Institute of Pacific Studies. University of Auckland. (2018). Our contribution to wellbeing [Annual report]. https://cdn.auckland.ac.nz/ assets/auckland/about-us/the-university/officialpublications/annual-report/annual-report-2018. pdf

Vaioleti, T. M. (2006). Talanoa research methodology: A developing position on Pacific research. Waikato Journal of Education, 12, 21-34. http:// doi.org/c6mj

Webber, M. (2008). Walking the space between: Identity and Māori/Pākehā. NZCER Press.

Williams, H. W. (1997). A dictionary of the Maori language (7th ed.). G. P. Publications.

Wolfgramm-Foliaki, 'E., \& Smith, H. (2020). He Vaka Moana: Navigating Māori and Pasifika student success through a collaborative research fellowship. MAI Journal, 9(1), 5-14. 